\title{
Recent advances in managing HIV-associated cryptococcal
}

\section{meningitis [version 1; peer review: 2 approved]}

\author{
Timothée Boyer-Chammard (D1) $12^{*}$, Elvis Temfack (iD) $3^{*}$, Alexandre Alanio ${ }^{1,4}$, \\ Joseph N. Jarvis 5,6 , Thomas S. Harrison7, Olivier Lortholary ${ }^{1,2}$
}

\footnotetext{
${ }^{1}$ Molecular Mycology Unit and National Reference Centre for Invasive Mycoses, UMR2000, CNRS, Institut Pasteur, Paris, France 2Université de Paris, Necker Pasteur Center for Infectious Diseases and Tropical Medicine, Hôpital Necker Enfants malades, AP-HP, IHU Imagine, Paris, France

${ }^{3}$ Douala General Hospital, Douala, Cameroon

4University Paris Diderot, Sorbonne Paris Cité, Université de Paris, Laboratory of Parasitology-Mycology, Saint-Louis Hospital, APHP, Paris, France

${ }^{5}$ Department of Clinical Research, Faculty of Infectious and Tropical Diseases, London School of Hygiene and Tropical Medicine, London, UK

${ }^{6}$ Botswana Harvard AIDS Institute Partnership, Gaborone, Botswana

${ }^{7}$ Institute of Infection and Immunity, St. George's University of London, London, UK

* Equal contributors
}

V1 First published: 28 May 2019, 8(F1000 Faculty Rev):743

https://doi.org/10.12688/f1000research.17673.1

Latest published: 28 May 2019, 8(F1000 Faculty Rev):743

https://doi.org/10.12688/f1000research.17673.1

\section{Abstract}

The recent development of highly sensitive and specific point-of-care tests has made it possible to diagnose HIV-associated cryptococcal meningitis within minutes. However, diagnostic advances have not been matched by new antifungal drugs and treatment still relies on old off-patent drugs: amphotericin B, flucytosine and fluconazole. Cryptococcal meningitis treatment is divided in three phases: induction, consolidation and maintenance. The induction phase, aimed at drastically reducing cerebrospinal fluid fungal burden, is key for patient survival. The major challenge in cryptococcal meningitis management has been the optimisation of induction phase treatment using the limited number of available medications, and major progress has recently been made. In this review, we summarise data from key trials which form the basis of current treatment recommendations for HIV-associated cryptococcal meningitis.

\section{Keywords}

Cryptococcus neoformans, cryptococcal meningo-encephalitis, Amphotericin B, Ambisome, Fluconazole, Flucytosine, advanced HIV disease, AIDS

\section{Open Peer Review}

Approval Status

1

2

version 1

28 May 2019

Faculty Reviews are review articles written by the prestigious Members of Faculty Opinions. The articles are commissioned and peer reviewed before publication to ensure that the final, published version is comprehensive and accessible. The reviewers who approved the final version are listed with their names and affiliations.

1. Carlos Franco-Paredes, University of Colorado Denver, Colorado, USA

2. Thomas Benfield, Hvidovre Hospital, University of Copenhagen, Copenhagen, Denmark 
Any comments on the article can be found at the end of the article.

Corresponding author: Olivier Lortholary (olivier.lortholary@wanadoo.fr)

Author roles: Boyer-Chammard T: Writing - Original Draft Preparation; Temfack E: Writing - Original Draft Preparation; Alanio A: Writing - Review \& Editing; Jarvis JN: Writing - Review \& Editing; Harrison TS: Writing - Review \& Editing; Lortholary O:

Conceptualization, Supervision, Writing - Review \& Editing

Competing interests: No competing interests were disclosed.

Grant information: T.B-C., A.A., J.N.J., T.S.H. and O.L. are all investigators on the AMBITION trial which is jointly funded through the European Developing Countries Clinical Trials Partnership (EDCTP), the Swedish International Development Cooperation Agency (SIDA), and the Wellcome Trust/Medical Research Council (UK)/UKAID Joint Global Health Trials.

The funders had no role in study design, data collection and analysis, decision to publish, or preparation of the manuscript.

Copyright: (c) 2019 Boyer-Chammard T et al. This is an open access article distributed under the terms of the Creative Commons Attribution License, which permits unrestricted use, distribution, and reproduction in any medium, provided the original work is properly cited.

How to cite this article: Boyer-Chammard T, Temfack E, Alanio A et al. Recent advances in managing HIV-associated cryptococcal meningitis [version 1; peer review: 2 approved] F1000Research 2019, 8(F1000 Faculty Rev):743

https://doi.org/10.12688/f1000research.17673.1

First published: 28 May 2019, 8(F1000 Faculty Rev):743 https://doi.org/10.12688/f1000research.17673.1 


\section{Introduction}

Cryptococcal meningitis (CM), a severe infection that is fatal without treatment, occurs primarily in patients with impaired cell-mediated immunity ${ }^{1}$. Prior to the human immunodeficiency virus (HIV) pandemic, most cases were described in solidorgan-transplant patients ${ }^{2}$. However, since 1993, CM became an acquired immune deficiency syndrome (AIDS)-defining infection in HIV-infected patients, and the number of cases increased rapidly, especially in Sub-Saharan Africa (SSA), where more than $90 \%$ of cases are HIV-associated ${ }^{3}$. In 2014, it was estimated that 223,000 cases of CM occurred globally, causing over 180,000 deaths, three quarters of which occurred in SSA, making $\mathrm{CM}$ the leading cause of adult meningitis in the region, responsible for $15 \%$ of all HIV-associated mortality ${ }^{4}$.

Ideally, prevention of HIV-related $\mathrm{CM}$ relies on prevention of severe immune suppression through early HIV diagnosis and initiation of antiretroviral therapy (ART) ${ }^{5}$. However, with current global ART coverage of about $60 \%$ and over $50 \%$ of $\mathrm{CM}$ cases occurring in ART-experienced patients ${ }^{7}$, the incidence of CM remains high $^{4}$, and timely CM diagnosis and optimal $\mathrm{CM}$ treatment are cornerstones for patient survival. Within the last decade, there have been major advances in the diagnosis of CM with the development of highly sensitive and highly specific point-of-care tests capable of providing results within 10 minutes $^{8,9}$. However, from a therapeutic perspective, no new medication for the treatment of $\mathrm{CM}$ has been developed or approved within the past two decades. Consequently, CM treatment still relies on three off-patent medications, each more than 25 years old: amphotericin $\mathrm{B}(\mathrm{AmB})$ and liposomal amphotericin B (L-AmB), flucytosine (5FC) and fluconazole (FLU) ${ }^{10,11}$. Clinically, CM presents as a sub-acute infection that requires prolonged treatment divided in three phases: induction, consolidation and maintenance ${ }^{11}$. The induction phase, which aims at drastically reducing cerebrospinal fluid (CSF) fungal burden within the first 2 weeks, is crucial for good patient outcomes $^{12,13}$. As such, the major challenge has been how best to use the limited antifungal treatment arsenal to optimise the induction phase for better patient survival. In low- and middleincome countries where $\mathrm{AmB}$ and $5 \mathrm{FC}$ are not always readily available, FLU monotherapy even at the highest doses has been associated with over $50 \%$ mortality during the first 10 weeks of treatment ${ }^{14-16}$, meaning that FLU monotherapy is not a suitable option for induction treatment of $\mathrm{CM}^{17}$. In this review, we summarise the major trials carried out within the last 5 years using combination antifungal therapy for the induction treatment of HIV-associated CM.

Recent advances in antifungal combination therapies One of the first randomised controlled trials comparing combination induction therapy for HIV-associated $\mathrm{CM}$ using $\mathrm{AmB}$ deoxycholate $(\mathrm{AmBd})$ at a higher dose of $1 \mathrm{mg} / \mathrm{kg}$ per day instead of the previously used $0.7 \mathrm{mg} / \mathrm{kg}$ per day was carried out in Vietnam $^{18}$. This three-group open-label trial, which enrolled 299 patients, aimed to determine whether 2-week combination therapy with either AmBd plus 5FC (at a dose of $100 \mathrm{mg} / \mathrm{kg}$ per day) or AmBd plus FLU (at a dose of $400 \mathrm{mg} /$ day) offered survival benefits over 4-week AmBd monotherapy. Fewer deaths occurred in the AmBd plus 5FC arm at day 14 (hazard ratio [HR] $0.57,95 \%$ confidence interval [CI] $0.30-1.08, P=0.08$ ) and at day 70 (HR $0.61,95 \%$ CI $0.39-0.97, P=0.04$ ). However, AmBd plus FLU did not show any significant survival benefits compared with AmBd monotherapy at days 14 and 70 (HR $0.78,95 \%$ CI $0.44-1.41, P=0.42$ and HR $0.71,95 \%$ CI $0.45-1.11, P=0.13$ respectively). This trial confirmed 14 days of AmBd $1 \mathrm{mg} / \mathrm{kg}$ per day plus $5 \mathrm{FC} 100 \mathrm{mg} /$ day as standard induction therapy for HIV-associated CM.

Nevertheless, the challenges of delivering 2 weeks of AmBd and AmB-related severe adverse events (SAEs) limit routine use of this regimen in resource-limited settings where monitoring and treating these SAEs are challenging ${ }^{19}$. Phase II trial results demonstrated that shorter-course AmBd was associated with fewer SAEs than a 2 week course, without diminution in rates of fungal clearance in the second week probably due to long half-life of $\mathrm{AmBd}$ in the brain ${ }^{20,21}$. Additionally, the oral combination of 5FC and high-dose FLU (1200 mg/day) was shown to have fungal clearance rates approaching those seen with $\mathrm{AmBd}$ alone $^{22}$. These options of short-course combination therapy were tested in an open-label phase 3 randomised non-inferiority multicentre Advancing Cryptococcal meningitis Treatment for Africa (ACTA) trial. ACTA was powered to compare the day 14 and day 70 survival rates of a short course of 1-week of $\mathrm{AmB}$ (combined with either high-dose FLU or 5FC in 1:1 ratio) and 2 weeks of oral combination (5FC plus high-dose FLU) with the standard 2-week of AmB combinations ${ }^{23}$. At 2 weeks, HRs of death were 0.82 (95\% CI 0.54-1.25) and 1.01 (95\% CI 0.68-1.51) in the oral and 1-week of AmBd groups respectively, compared with the 2 -week of $\mathrm{AmBd}$ groups. In addition, at 10 weeks, HRs were 0.83 (95\% CI 0.61-1.13) for oral and 0.89 (95\% CI 0.66-1.21) for the 1-week regimen, in comparison with the standard groups. However, as partner drug to $\mathrm{AmB}, 5 \mathrm{FC}$ was superior to FLU with week-10 mortality (HR 0.62 , 95\% CI $0.45-0.84, P=0.002$ ). Separate analyses of each regimen as compared with standard 2-week of $\mathrm{AmBd}$ plus 5FC showed 1-week of AmBd plus 5FC to have the lowest 10 -week mortality (HR 0.59 , 95\% CI $0.36-0.96$ ) followed by oral combination of FLU and 5FC (HR 0.91, 95\% CI 0.63-1.33).

In a recent systematic review and meta-analysis aggregating data from 13 studies encompassing 2426 patients, pairwise analysis showed that, at 10 weeks, 1 -week of $\mathrm{AmBd}$ plus 5FC is superior to other regimens for the induction treatment of HIV-associated CM and that oral combination of 5FC plus highdose FLU is the next best option if $\mathrm{AmBd}$ is not available or cannot be given safely ${ }^{24}$.

These two regimens have since been endorsed as the first- and second-line preferred regimens in resource-limited settings in the latest World Health Organization (WHO) guidelines ${ }^{11}$ (Table 1).

The use of L-AmB is known to be associated with fewer adverse events compared with $\mathrm{AmBd}$ formulation ${ }^{25}$. Again, with the aims of simplifying treatment and reducing adverse events and costs while maintaining efficacy, and based on pre-clinical data showing that L-AmB has a long tissue half-life and effectively 
Table 1. World Health Organization 2018 guidelines for the management of cryptococcal disease in adults with HIV.

\begin{tabular}{|c|c|c|c|c|}
\hline \multicolumn{3}{|c|}{ Induction phase (2 weeks) } & \multirow{2}{*}{$\begin{array}{c}\text { Consolidation } \\
\text { phase }\end{array}$} & \multirow{2}{*}{$\begin{array}{c}\text { Maintenance phase (secondary prophylaxis) } \\
\text { After week } 10\end{array}$} \\
\hline \multirow[t]{2}{*}{ Preferred regimen } & First week & Second week & & \\
\hline & $A m B+5 F C$ & High-dose FLU & \multirow{3}{*}{$\begin{array}{l}\text { Fluconazole } \\
\text { (800 mg daily) }\end{array}$} & Fluconazole (200 mg daily) \\
\hline \multirow{2}{*}{$\begin{array}{l}\text { Alternative regimens } \\
\text { Depending on availability of } \\
\text { drugs }\end{array}$} & \multicolumn{2}{|c|}{$5 F C+$ high-dose FLU } & & Until the patient is adherent to ART and antifungal \\
\hline & \multicolumn{2}{|c|}{ AmB + high-dose FLU } & & $\begin{array}{c}\text { maintenance treatment for at least } 1 \text { year and has either } \\
\text { - a CD4 count of at least } 100 \text { cells } / \mathrm{mm}^{3} \text { and a fully } \\
\text { suppressed viral load } \\
\text { - or a CD4 count of at least } 200 \text { cells } / \mathrm{mm}^{3}\end{array}$ \\
\hline \multicolumn{3}{|c|}{$\begin{array}{l}\text { Monitoring and management of raised intracranial pressure } \\
\text { are recommended. } \\
\text { Routine use of adjunctive corticosteroid therapy is not } \\
\text { recommended. }\end{array}$} & \multicolumn{2}{|c|}{$\begin{array}{c}\text { ART initiation should be deferred by } 4 \text { to } 6 \text { weeks from the initiation of } \\
\text { antifungal treatment. }\end{array}$} \\
\hline
\end{tabular}

"High-dose FLU" refers to fluconazole, $1200 \mathrm{mg}$ daily, orally. 5FC, flucytosine (100 mg/kg per day, divided into four doses per day, orally); AmB, amphotericin B deoxycholate $(1.0 \mathrm{mg} / \mathrm{kg}$ per day, intravenously); ART, antiretroviral therapy. Adapted from World Health Organization. Guidelines for the diagnosis, prevention, and management of cryptococcal disease in HIV-infected adults, adolescents and children. Geneva: World Health Organization; 2018 March $2018{ }^{11}$.

penetrates brain tissue ${ }^{26}$, the Ambisome Therapy Induction Optimisation (AMBITION) phase II trial testing short-course high-dose L-AmB was recently completed ${ }^{27}$. In Botswana and Tanzania, 80 HIV-infected patients with $\mathrm{CM}$ were recruited and randomly assigned to four different arms: the standard 14-day therapy of L-AmB $3 \mathrm{mg} / \mathrm{kg}$ per day; a single high dose of L-AmB $10 \mathrm{mg} / \mathrm{kg}$ at day 1; two doses of L-AmB: $10 \mathrm{mg} / \mathrm{kg}$ at day 1 and $5 \mathrm{mg} / \mathrm{kg}$ at day 3; or three doses of L-AmB: $10 \mathrm{mg} / \mathrm{kg}$ at day 1 and $5 \mathrm{mg} / \mathrm{kg}$ at days 3 and 7 . All participants also received high-dose FLU (1200 mg/day). The primary outcome was early fungicidal activity, which was found to be non-inferior to the control arm in all three short-course arms. The overall 10 -week mortality was $29 \%(n=23)$, there was no statistical difference between arms, and all arms were well tolerated.

These phase II data have informed the AMBITION phase III trial, which started recruiting in early 2018, using mortality within 10 weeks after randomisation as a clinical primary endpoint and aiming to recruit $850 \mathrm{HIV}$-infected patients with $\mathrm{CM}$ in five SSA countries ${ }^{28}$. The participants are being randomly assigned to receive either the new WHO-recommended first-line therapy (7 days of AmBd $1 \mathrm{mg} / \mathrm{kg}$ per day plus $5 \mathrm{FC} 100 \mathrm{mg} / \mathrm{kg}$ per day followed by 7 days of high-dose FLU $1200 \mathrm{mg} /$ day) or a high single dose of L-AmB $10 \mathrm{mg} / \mathrm{kg}$ at day 1 , given with 14 days of 5FC and high-dose FLU.

\section{Recent advances in the management of high intracranial pressure}

High baseline intracranial pressure (ICP) of more than $250 \mathrm{~mm}$ $\mathrm{H}_{2} \mathrm{O}$ has been shown to be associated with poor short-term survival in patients with $\mathrm{CM}^{29}$. A CSF pro-inflammatory cytokine response with increased levels of tumour necrosis factor-alpha (TNF- $\alpha$ ) was suggested to be associated with raised $\mathrm{ICP}^{30}$, and inhibition of pro-inflammatory response with immune modulators like dexamethasone could be associated with a larger reduction in CSF opening pressure during the first 2 weeks of induction therapy ${ }^{31}$. However, dexamethasone-associated decline in TNF- $\alpha$ levels was also associated with slow fungal clearance and poor outcome, contraindicating the use of dexamethasone in the management of raised $\mathrm{ICP}^{32}$. In a combined cohort on determinants of mortality in 501 patients with HIV$\mathrm{CM}$, in a context of strict management of high ICP according to guidelines ${ }^{30}$ with repeated therapeutic lumbar punctures (LPs), high pressures were not associated with increased mortality. In the Cryptococcal Optimal ART Timing (COAT) trial, the effect of therapeutic LP was also found to be associated with improved survival ${ }^{33}$.

Recent advances in initiation of antiretroviral therapy ART initiation is urgently needed in HIV-infected patients with advanced disease ${ }^{34}$. Even so, paradoxical cryptococcal immune reconstitution inflammatory syndrome still occurs in 15 to $20 \%$ of patients with CM after initiating ART $^{35}$. Generally, cases are diagnosed 1 to 2 months after ART initiation ${ }^{36}$. Very early initiation of ART (within 3 days of initiation of antifungal therapy) in patients with $\mathrm{CM}$ increased mortality compared with a delay of 10 weeks after diagnosis in FLUtreated patients in Zimbabwe ${ }^{37}$. In the larger COAT trial $^{33}$, ART-naïve HIV-infected patients with CM were enrolled in Uganda and South Africa and randomly assigned after 7 to 11 days of AmBd plus FLU combination therapy to either early (within 48 hours after randomisation) or delayed (4 weeks after randomisation) initiation of ART. Recruitment was stopped at 177 of the initially planned 500 enrolments because mortality was significantly higher with early initiation (HR 1.73, 95\% CI 1.06-2.82, $P=0.03$ ); this effect was most marked in patients with low CSF white cell count (HR 3.87, 95\% CI 1.41-10.58, $P=0.008$ ). A Cochrane systematic review ${ }^{38}$ including four trials and 294 adults recently concluded that, for HIV-infected patients with 
$\mathrm{CM}$ in low- and middle-income countries, there is a higher risk of all-cause mortality if ART is initiated early (risk ratio $1.42,95 \%$ CI $1.02-1.97)$.

The management of ART-exposed patients who develop CM remains challenging, and lessons are being learned through ongoing experience. The 2018 WHO guidelines for HIV-associated CM management suggest that initiation, restart or switch of ART be carried out after 4 to 6 weeks of antifungal therapy ${ }^{11}$.

\section{Recent advances in adjuvant therapies}

Adjuvant steroid therapy is commonly used in HIV-negative patients with pneumococcal or tuberculous meningitis and is associated with improved survival ${ }^{39,40}$; however, until recently, the utility of steroids in HIV-associated CM was unknown. In the CryptoDex randomised double-blind placebo-controlled trial $^{31}$, HIV-infected patients with $\mathrm{CM}$ receiving an induction combination therapy of AmB and FLU in six countries in Africa and Asia were randomly assigned to receive either dexamethasone intravenously for the first 2 weeks and then orally until the sixth week or placebo for 6 weeks. Mortality at 10 weeks as the primary outcome showed no difference between the dexamethasone and placebo groups (47\% versus $41 \%$ respectively; HR $1.11,95 \%$ CI $0.84-1.47, P=0.45)$. The trial was stopped for safety reasons after the enrolment of 451 out of the planned 880 patients because the data safety monitoring board determined that dexamethasone was causing harm across key outcomes. Dexamethasone was significantly associated with slower rates of decline in CSF fungal count than placebo and was also associated with more adverse events and disability. Recent reports show that this slow fungal clearance and increased mortality could be due to a dexamethasone-induced increased rate of decline in CSF TNF- $\alpha^{32}$. However, dexamethasone was also significantly associated with a greater reduction in CSF opening pressure during the first 2 weeks than the placebo.

The addition of sertraline, a selective serotonin reuptake inhibitor, to the standard induction therapy has been suggested given limited evidence for in vitro activity against Cryptococcus ${ }^{41}$. A phase II dose-finding study ${ }^{42}$ postulated that adjuvant sertraline therapy might increase cryptococcal CSF clearance compared with historical control data. This was recently tested in the Adjunctive Sertraline for the Treatment of HIV-Associated Cryptococcal Meningitis (ASTRO-CM) randomised placebocontrolled trial in Uganda, where $460 \mathrm{HIV}$-infected patients with $\mathrm{CM}$ receiving combination therapy of $\mathrm{AmB}$ and FLU were randomly assigned to receive either sertraline (400 $\mathrm{mg} /$ day for 2 weeks and then $200 \mathrm{mg} /$ day for 10 weeks) or placebo in addition to the standard antifungal therapy. The trial was prematurely stopped for futility because 18-week mortality was similar in the sertraline and placebo groups $(52 \%$ and $46 \%$ respectively, HR $1.21, P=0.15)^{43}$.

\section{Conclusions}

The management of HIV-associated CM has significantly changed in the past few years. The advent of highly sensitive and highly specific point-of-care tests has reduced diagnostic turnaround time to about 10 minutes. One-week of $\mathrm{AmB}$ plus 5FC and 2-week oral combination of high-dose FLU and 5FC are currently preferred first- and second-line induction therapy in resource-limited settings. Simpler induction regimens with $\mathrm{L}-\mathrm{AmB}$ are being tested in a phase 3 trial. ART initiation following induction therapy should be deferred by 4 to 6 weeks, although managing ART-experienced patients remains a challenge. Dexamethasone or sertraline as adjunctive induction therapy is not recommended. Repeated therapeutic LP is recommended for the management of raised ICP. Progress is being made in access to essential drugs as preferential pricing for L-AmB has been extended from visceral leishmaniasis to $\mathrm{CM}$ and wide access to generic 5FC is expected given ongoing personal and international efforts.

\section{Grant information}

T.B-C., A.A., J.N.J., T.S.H. and O.L. are all investigators on the AMBITION trial which is jointly funded through the European Developing Countries Clinical Trials Partnership (EDCTP), the Swedish International Development Cooperation Agency (SIDA), and the Wellcome Trust/Medical Research Council (UK)/UKAID Joint Global Health Trials.

The funders had no role in study design, data collection and analysis, decision to publish, or preparation of the manuscript.
1. F Kwon-Chung KJ, Fraser JA, Doering TL, et al:: Cryptococcus neoformans and Cryptococcus gattii, the etiologic agents of cryptococcosis. Cold Spring Harb Perspect Med. 2014; 4(7): a019760.

PubMed Abstract | Publisher Full Text | Free Full Text | F1000 Recommendation

2. F Pappas PG, Alexander BD, Andes DR, et al.: Invasive fungal infections among organ transplant recipients: results of the Transplant-Associated Infection Surveillance Network (TRANSNET). Clin Infect Dis. 2010; 50(8): 1101-11. PubMed Abstract | Publisher Full Text | F1000 Recommendation

3. F Jarvis JN, Meintjes G, Williams A, et al.: Adult meningitis in a setting of high HIV and TB prevalence: findings from 4961 suspected cases. BMC Infect Dis. 2010; 10: 67.

PubMed Abstract | Publisher Full Text | Free Full Text | F1000 Recommendation
4. F Rajasingham R, Smith RM, Park BJ, et al:: Global burden of disease of HIVassociated cryptococcal meningitis: an updated analysis. Lancet Infect Dis. 2017; 17(8): 873-81.

PubMed Abstract | Publisher Full Text | Free Full Text | F1000 Recommendation

5. World Health Organisation: Consolidated guidelines on the use of antiretroviral drugs for treating and preventing HIV infection. Recommendations for a public health approach. Second edition. 2016. PubMed Abstract

6. UNAIDS: Fact sheet - Latest global and regional statistics on the status of the AIDS epidemic. 2018.

Reference Source

7. Tenforde MW, Mokomane M, Leeme T, et al:: Advanced Human 
Immunodeficiency Virus Disease in Botswana Following Successful Antiretroviral Therapy Rollout: Incidence of and Temporal Trends in Cryptococcal Meningitis. Clin Infect Dis. 2017; 65(5): 779-86.

PubMed Abstract | Publisher Full Text | Free Full Text

8. BIOSYNEX: Test CryptoPS. 2017; [cited 20 June 2017] Reference Source

9. IMMY: CrAg LFA. 2017

Reference Source

10. Loyse A, Dromer F, Day J, et al.: Flucytosine and cryptococcosis: time to urgently address the worldwide accessibility of a 50-year-old antifungal. $J$ Antimicrob Chemother. 2013; 68(11): 2435-44.

PubMed Abstract | Publisher Full Text | Free Full Tex

11. World Health Organisation: Guidelines for the diagnosis, prevention, and management of cryptococcal disease in HIV-infected adults, adolescents and children. Supplement to the $\mathbf{2 0 1 6}$ consolidated guidelines on the use of antiretroviral drugs for treating and preventing HIV infection. 2018; [cited 2018]. Reference Source

12. F Bicanic T, Wood R, Meintjes G, et al:: High-dose amphotericin B with flucytosine for the treatment of cryptococcal meningitis in HIV-infected patients: a randomized trial. Clin Infect Dis. 2008; 47(1): 123-30. PubMed Abstract | Publisher Full Text | F1000 Recommendation

13. F Pappas PG, Chetchotisakd P, Larsen RA, et al:: A phase II randomized trial of amphotericin $B$ alone or combined with fluconazole in the treatment of HIVassociated cryptococcal meningitis. Clin Infect Dis. 2009; 48(12): 1775-83. PubMed Abstract | Publisher Full Text | F1000 Recommendation

14. Rothe C, Sloan DJ, Goodson P, et al:: A prospective longitudinal study of the clinical outcomes from cryptococcal meningitis following treatment induction with 800 mg oral fluconazole in Blantyre, Malawi. PLoS One. 2013; 8(6): e6731 PubMed Abstract | Publisher Full Text | Free Full Text

15. Luma HN, Temfack E, Halle MP, et al.: Cryptococcal meningoencephalitis in human immunodeficiency virus/acquired immunodeficiency syndrome in douala, cameroon: a cross sectional study. N Am J Med Sci. 2013; 5(8): 486-91. PubMed Abstract | Publisher Full Text | Free Full Text

16. Gaskell KM, Rothe C, Gnanadurai R, et al:: A prospective study of mortality from cryptococcal meningitis following treatment induction with $1200 \mathrm{mg}$ ora fluconazole in Blantyre, Malawi. PLoS One. 2014; 9(11): e110285. PubMed Abstract | Publisher Full Text | Free Full Text

17. F Beyene T, Zewde AG, Balcha A, et al:: Inadequacy of High-Dose Fluconazole Monotherapy Among Cerebrospinal Fluid Cryptococcal Antigen (CrAg)-Positive Human Immunodeficiency Virus-Infected Persons in an Ethiopian CrAg Screening Program. Clin Infect Dis. 2017; 65(12): 2126-9. PubMed Abstract | Publisher Full Text | Free Full Text | F1000 Recommendation

18. F Day JN, Chau TTH, Wolbers M, et al:: Combination antifungal therapy for cryptococcal meningitis. N Engl J Med. 2013; 368(14): 1291-302. PubMed Abstract | Publisher Full Text | Free Full Text | F1000 Recommendation

19. Loyse $A$, Thangaraj $H$, Easterbrook $P$, et al.: Cryptococcal meningitis: improving access to essential antifungal medicines in resource-poor countries. Lancet Infect Dis. 2013; 13(7): 629-37.

PubMed Abstract | Publisher Full Text

20. Muzoora CK, Kabanda T, Ortu G, et al.: Short course amphotericin B with high dose fluconazole for HIV-associated cryptococcal meningitis. J Infect. 2012; 64(1): 76-81.

PubMed Abstract | Publisher Full Text

21. Jackson AT, Nussbaum JC, Phulusa J, et al:: A phase II randomized controlled trial adding oral flucytosine to high-dose fluconazole, with short-course amphotericin B, for cryptococcal meningitis. AIDS. 2012; 26(11): 1363-70. PubMed Abstract | Publisher Full Text | Free Full Text

22. F Nussbaum JC, Jackson A, Namarika D, et al:: Combination flucytosine and high-dose fluconazole compared with fluconazole monotherapy for the treatment of cryptococcal meningitis: a randomized trial in Malawi. Clin Infect Dis. 2010; 50(3): 338-44.

PubMed Abstract | Publisher Full Text | Free Full Text | F1000 Recommendation

23. F Molloy SF, Kanyama C, Heyderman RS, et al:: Antifungal Combinations for Treatment of Cryptococcal Meningitis in Africa. N Engl J Med. 2018; 378(11): 1004-17.

PubMed Abstract | Publisher Full Text | F1000 Recommendation

24. Tenforde MW, Shapiro AE, Rouse B, et al:: Treatment for HIV-associated cryptococcal meningitis. Cochrane Database Syst Rev. 2018; 7: CD005647. PubMed Abstract | Publisher Full Text

25. Hamill RJ, Sobel JD, El-Sadr W, et al: Comparison of 2 doses of liposomal amphotericin B and conventional amphotericin B deoxycholate for treatment of AIDS-associated acute cryptococcal meningitis: a randomized, double-blind clinical trial of efficacy and safety. Clin Infect Dis. 2010; 51(2): 225-32. PubMed Abstract | Publisher Full Text

26. Lestner J, McEntee L, Johnson A, et al: Experimental Models of Short Courses of Liposomal Amphotericin B for Induction Therapy for Cryptococcal Meningitis. Antimicrob Agents Chemother. 2017; 61(6): pii: e00090-17. PubMed Abstract | Publisher Full Text | Free Full Text

27. Jarvis JN, Leeme TB, Molefi M, et al:: Short-course High-dose Liposomal Amphotericin B for Human Immunodeficiency Virus-associated Cryptococcal Meningitis: A Phase 2 Randomized Controlled Trial. Clin Infect Dis. 2019; 68(3): 393-401. PubMed Abstract | Publisher Full Text | Free Full Text

28. Lawrence DS, Youssouf N, Molloy SF, et al:: AMBIsome Therapy Induction OptimisatioN (AMBITION): High Dose AmBisome for Cryptococcal Meningitis Induction Therapy in sub-Saharan Africa: Study Protocol for a Phase 3 Randomised Controlled Non-Inferiority Trial. Trials. 2018; 19(1): 649. PubMed Abstract | Publisher Full Text | Free Full Text

29. Graybill JR, Sobel J, Saag M, et al.: Diagnosis and management of increased intracranial pressure in patients with AIDS and cryptococcal meningitis. The NIAID Mycoses Study Group and AIDS Cooperative Treatment Groups. Clin Infect Dis. 2000; 30(1): 47-54.

PubMed Abstract | Publisher Full Text

30. Jarvis $\mathrm{JN}$, Bicanic $T$, Loyse $A$, et al: Determinants of mortality in a combined cohort of 501 patients with HIV-associated Cryptococcal meningitis: implications for improving outcomes. Clin Infect Dis. 2014; 58(5): 736-45. PubMed Abstract | Publisher Full Text | Free Full Text

31. F Beardsley J, Wolbers M, Kibengo FM, et al:: Adjunctive Dexamethasone in HIV-Associated Cryptococcal Meningitis. N Engl J Med. 2016; 374(6): 542-54. PubMed Abstract | Publisher Full Text | Free Full Text | F1000 Recommendation

32. F Beardsley J, Hoang NLT, Kibengo FM, et al.: Do intra-cerebral cytokine responses explain the harmful effects of dexamethasone in HIV-associated cryptococcal meningitis? Clin Infect Dis. 2019; 68(9): 1494-1501. PubMed Abstract | Publisher Full Text | Free Full Text | F1000 Recommendation

33. F Boulware DR, Meya DB, Muzoora C, et al: Timing of Antiretroviral Therapy after Diagnosis of Cryptococcal Meningitis. N Engl J Med. 2014; 370(26): 2487-98. PubMed Abstract | Publisher Full Text | Free Full Text | F1000 Recommendation

34. World Health Organisation: Guidelines for Managing Advanced HIV Disease and Rapid Initiation of Antiretroviral Therapy. 2017 PubMed Abstract

35. Jarvis JN, Harrison TS: Understanding Causal Pathways in Cryptococcal Meningitis Immune Reconstitution Inflammatory Syndrome. J Infect Dis. 2019; 219(3): 344-6.

PubMed Abstract | Publisher Full Text

36. Longley N, Harrison TS, Jarvis JN: Cryptococcal immune reconstitution inflammatory syndrome. Curr Opin Infect Dis. 2013; 26(1): 26-34. PubMed Abstract | Publisher Full Text

37. F Makadzange AT, Ndhlovu CE, Takarinda K, et al.: Early versus Delayed Initiation of Antiretroviral Therapy for Concurrent HIV Infection and Cryptococcal Meningitis in Sub-Saharan Africa. Clin Infect Dis. 2010; 50(11): 1532-8.

PubMed Abstract | Publisher Full Text | F1000 Recommendation

38. F Eshun-Wilson I, Okwen MP, Richardson M, et al:: Early versus delayed antiretroviral treatment in HIV-positive people with cryptococcal meningitis. Cochrane Database Syst Rev. 2018; 7: CD009012.

PubMed Abstract | Publisher Full Text | F1000 Recommendation

39. Thwaites GE, Nguyen DB, Nguyen HD, et al.: Dexamethasone for the treatment of tuberculous meningitis in adolescents and adults. N Engl J Med. 2004 351(17): 1741-51

PubMed Abstract | Publisher Full Text

40. de Gans J, van de Beek D, European Dexamethasone in Adulthood Bacteria Meningitis Study Investigators: Dexamethasone in adults with bacterial meningitis. N Engl J Med. 2002; 347(20): 1549-56.

PubMed Abstract | Publisher Full Text

41. F Zhai B, Wu C, Wang L, et al:: The antidepressant sertraline provides a promising therapeutic option for neurotropic cryptococcal infections. Antimicrob Agents Chemother. 2012; 56(7): 3758-66.

PubMed Abstract | Publisher Full Text | Free Full Text | F1000 Recommendation

42. $\mathrm{F}$ Rhein J, Morawski BM, Hullsiek KH, et al.: Efficacy of adjunctive sertraline for the treatment of HIV-associated cryptococcal meningitis: an open-label dose-ranging study. Lancet Infect Dis. 2016; 16(7): 809-18.

PubMed Abstract | Publisher Full Text | Free Full Text | F1000 Recommendation

43. Rhein J, Hullsiek K, Tugume L, et al:: Adjunctive sertraline in HIV-associated cryptococcal meningitis. In Conference on retroviruses and opportunistic infections. Boston. 2018.

Reference Source 


\section{Open Peer Review}

\section{Current Peer Review Status:}

\section{Editorial Note on the Review Process}

Faculty Reviews are review articles written by the prestigious Members of Faculty Opinions. The articles are commissioned and peer reviewed before publication to ensure that the final, published version is comprehensive and accessible. The reviewers who approved the final version are listed with their names and affiliations.

\section{The reviewers who approved this article are:}

\section{Version 1}

\section{Thomas Benfield}

Department of Infectious Diseases, Hvidovre Hospital, University of Copenhagen, Copenhagen, Denmark

Competing Interests: No competing interests were disclosed.

\section{Carlos Franco-Paredes}

Department of Medicine, Division of Infectious Diseases, University of Colorado Denver, Colorado, USA

Competing Interests: No competing interests were disclosed.

The benefits of publishing with F1000Research:

- Your article is published within days, with no editorial bias

- You can publish traditional articles, null/negative results, case reports, data notes and more

- The peer review process is transparent and collaborative

- Your article is indexed in PubMed after passing peer review

- Dedicated customer support at every stage

For pre-submission enquiries, contact research@f1000.com 